This article was downloaded by: [Michigan State University]

On: 27 December 2014, At: 02:44

Publisher: Taylor \& Francis

Informa Ltd Registered in England and Wales Registered Number: 1072954 Registered

office: Mortimer House, 37-41 Mortimer Street, London W1T 3JH, UK

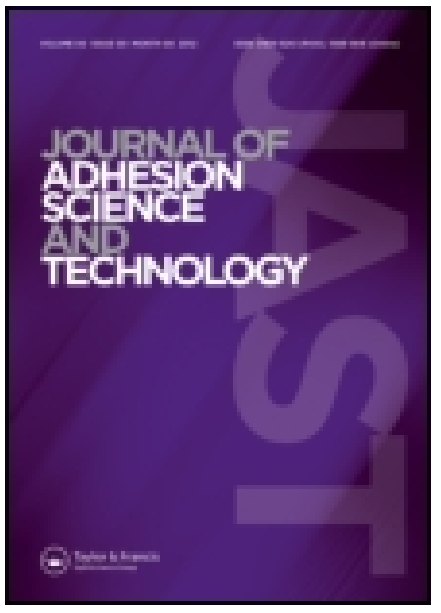

\title{
Journal of Adhesion Science and Technology
}

Publication details, including instructions for authors and subscription information:

http://www.tandfonline.com/loi/tast20

\section{Epoxysilane as adhesion promoter in duplex system}

\author{
Cecilia Deyá $^{a}$ \\ La Plata , Argentina \\ Published online: 11 Dec 2012.
}

${ }^{a}$ CIDEPINT - Centro de Investigación y Desarrollo en Tecnología de Pinturas, (CIC-CONICET) , Av. 52 s/n entre 121 y 122. B1900AYB,

To cite this article: Cecilia Deyá (2013) Epoxysilane as adhesion promoter in duplex system, Journal of Adhesion Science and Technology, 27:14, 1548-1562, DOI: 10.1080/01694243.2012.747728

To link to this article: http://dx.doi.org/10.1080/01694243.2012.747728

\section{PLEASE SCROLL DOWN FOR ARTICLE}

Taylor \& Francis makes every effort to ensure the accuracy of all the information (the "Content") contained in the publications on our platform. However, Taylor \& Francis, our agents, and our licensors make no representations or warranties whatsoever as to the accuracy, completeness, or suitability for any purpose of the Content. Any opinions and views expressed in this publication are the opinions and views of the authors, and are not the views of or endorsed by Taylor \& Francis. The accuracy of the Content should not be relied upon and should be independently verified with primary sources of information. Taylor and Francis shall not be liable for any losses, actions, claims, proceedings, demands, costs, expenses, damages, and other liabilities whatsoever or howsoever caused arising directly or indirectly in connection with, in relation to or arising out of the use of the Content.

This article may be used for research, teaching, and private study purposes. Any substantial or systematic reproduction, redistribution, reselling, loan, sub-licensing, systematic supply, or distribution in any form to anyone is expressly forbidden. Terms \& Conditions of access and use can be found at http://www.tandfonline.com/page/termsand-conditions 


\title{
Epoxysilane as adhesion promoter in duplex system
}

\author{
Cecilia Deyá* \\ CIDEPINT - Centro de Investigación y Desarrollo en Tecnología de Pinturas, (CIC-CONICET), Av. 52 \\ $s / n$ entre 121 y 122. B1900AYB, La Plata, Argentina
}

(Received 28 June 2011; final version received 3 May 2012; accepted 20 October 2012)

\begin{abstract}
Coatings are one of the most used protection methods for metals. Metallic coatings, such as zinc and its alloys, are used to protect steel in mild corrosive environments. In aggressive environments, on the other hand, organic coatings must be employed in the so-called duplex systems. However, the galvanized steel/organic coating adhesion is a problem and many attempts had been done to solve it with the incorporation of a chromate-based or phosphate-based interlayer. Nowadays, the use of these compounds is questioned due to their environmental impact and new adhesion promoters, like silanes, are being investigated. The aim of this paper was to study the adhesion and the anticorrosive behavior of a duplex system with a layer of glycidoxypropyltrimethoxysilane ( $\gamma$-GPS) between the zinc and the coating. Polarization tests and corrosion potential measurements were done on the $\gamma$-GPS/galvanized steel to select the better anticorrosive pretreatment conditions for the application of an organic traditional paint. Dried and wet adhesion of the coating to the pretreated substrate was studied by the standard tape test. Salt spray test and electrochemical noise technique were employed to study the corrosion behavior of the duplex systems. Results showed that the films of $\gamma$-GPS formed on galvanized steel diminished the corrosion current of the metal, but they do not protect the substrate by a barrier effect. The incorporation of the pretreatment in the duplex system increased the adhesion of the paint, especially when the pretreated substrate was cured $1 \mathrm{~h}$ at $200^{\circ} \mathrm{C}$.
\end{abstract}

Keywords: thin films; coatings; corrosion tests; FTIR; adhesion promoter

\section{Introduction}

Anticorrosion protection of structural materials is of great concern because corrosion modifies the physical and mechanical properties of metals and shortens their useful life with constant economic losses. Metallic and organic coatings are one of the most used protection methods. Metallic coatings, such as zinc and its alloys, are used to protect steel in mild corrosive environments. However, in aggressive environment, organic coatings are employed, besides the metallic coating, in the so-called duplex systems. The duplex systems posses a longer life than each of the coatings used independently [1-3]. This improved corrosion protection is attributed to four effects: (a) the cathodic protection afforded by zinc, (b) the blocking of zinc film defects by zinc corrosion products, (c) the barrier, and (d) the inhibitive properties of the organic coating. However, the galvanized steel/organic coating adhesion is still a problem and blisters or delamination may occur [3]. This drawback was solved in the past with the incorporation of a chromate or phosphate-based interlayer, but nowadays, the use of these compounds are questioned due to their environmental impact.

*Email: pinturashigienicas@cidepint.gov.ar 
The use of silanes as coupling agents improves metal/organic coating adhesion and the anticorrosive performance of the duplex system as a whole [4-8]. The general formula of the silanes is $\mathrm{R}-\mathrm{OSi}-\left(\mathrm{OR}^{\prime}\right)_{3}$, being $\mathrm{R}$ a nonhydrolysable organic-functional group and $\mathrm{R}^{\prime}$ an organic group which may hydrolyze followed by further condensation. Adhesion is normally achieved by a covalent bond $\mathrm{Si}-\mathrm{O}-\mathrm{Me}$ which involved the $\mathrm{R}^{\prime}$ group. The $\mathrm{R}$ group can be chosen to be compatible with the resin in the organic coating, enhancing silane-coating adhesion [5-7]. Moreover, with the incorporation of silanes, the toxic interlayer of the duplex system coating is replaced by an environmentally friendly sol-gel hybrid one.

\section{Experimental}

A $1 \%$, by weight, glycidoxypropyltrimethoxysilane (from now on $\gamma$-GPS) aqueous solution was prepared and stirred for $1 \mathrm{~h}$. As very little oligomerization has occurred, the silane solution could be deposited without high molecular weight oligomers being present. The oligomerization needed for good adhesion of the silane films to the substrate will be obtained by drying the film after application [8-11].

The substrate employed to carry out this research was commercial-grade galvanized steel plates, $2 \times 8 \mathrm{~cm}^{2}$. The thickness of the zinc coating was determined according to the standard ASTM D A90/A90 M, employing 25\% $\mathrm{H}_{2} \mathrm{SO}_{4}$ and by optic microscopic observation. Before use, panels were degreased by immersion in boiling $5 \% \mathrm{Na}_{2} \mathrm{CO}_{3}$ solution, rinsed thoroughly with distilled water and dried under laboratory conditions (temperature: $25^{\circ} \mathrm{C}$, relative humidity: $65 \%$ ). This procedure also ensured the wettability of the substrate by the silane solution.

In order to obtain the sol-gel films, the panels were immersed in the $\gamma$-GPS solution for $20 \mathrm{~s}$ and withdrawn at a rate of $32 \mathrm{~cm} / \mathrm{min}$.

Pretreated panels were placed in an oven at a suitable temperature and during different periods of time to cure the film. Two temperatures $\left(100\right.$ and $\left.200^{\circ} \mathrm{C}\right)$ and three curing times $(0.5,1.0$ and $2.0 \mathrm{~h})$ were tested. Moreover, pretreated panels dried at $25^{\circ} \mathrm{C}$ for $48 \mathrm{~h}$ were also tested. The samples will be named from now on with a letter indicating the curing temperature $\left(\mathrm{C}\right.$ indicates $100{ }^{\circ} \mathrm{C}$ and $\left.\mathrm{D}, 200^{\circ} \mathrm{C}\right)$ and a number indicating the curing time $(0$ implies $0.5 \mathrm{~h}, 11.0 \mathrm{~h}$ and $22.0 \mathrm{~h}$ ), and $\mathrm{R}$ for the sample cured at $25^{\circ} \mathrm{C}$ for $48 \mathrm{~h}$. For example, $\mathrm{C} 0$ indicates the sample cured at $100^{\circ} \mathrm{C}$ for $0.5 \mathrm{~h}$. Letter B stands for the nonpretreated control samples. Table 1 shows the details of the labels. testing.

The cured panels were kept in a desiccator, at room temperature, for three days before

\subsection{Pretreated galvanized steel}

A Potentiostat/Galvanostat EG\&G PAR Model 273A plus SOFTCORR 352 software was employed to obtain polarization curves of pretreated panels after 1,6 , and $25 \mathrm{~h}$ of immersion

Table 1. Labeled of the samples.

\begin{tabular}{lcc}
\hline Sample & Curing temperature $\left({ }^{\circ} \mathrm{C}\right)$ & Curing time (h) \\
\hline $\mathrm{R}$ & 25 & 48 \\
$\mathrm{C} 0$ & 100 & 0.5 \\
$\mathrm{C} 1$ & 100 & 1.0 \\
$\mathrm{C} 2$ & 100 & 2.0 \\
$\mathrm{D} 0$ & 200 & 0.5 \\
$\mathrm{D} 1$ & 200 & 1.0 \\
$\mathrm{D} 2$ & 200 & 2.0 \\
\hline
\end{tabular}


in $\mathrm{NaCl} 0.5 \mathrm{~mol} / \mathrm{L}$. The measurements were performed using a three electrode cell consisting of a platinum grid as counter electrode, a saturated calomel electrode (SCE) as reference electrode, and the working electrode (pretreated galvanized steel). The swept amplitude was $\pm 250 \mathrm{mV}$ from the open circuit potential (O.C.) and the scan rate was $0.5 \mathrm{mV} \mathrm{s}^{-1}$.

Polarization resistance with and without IR drop-compensation ( $R_{\mathrm{p}}^{*}$ and $R_{\mathrm{p}}$, respectively) were obtained from shorter scans $( \pm 20 \mathrm{mV}$ O.C.) after 1,6 , and $25 \mathrm{~h}$ of immersion in $0.05 \mathrm{~mol} / \mathrm{L} \mathrm{NaCl}$, being the scan rate $0.166 \mathrm{mV} \mathrm{s}^{-1}$. The measurements were carried out employing the same cell and equipment as before. Corrosion current density was determined from these polarization curves.

Corrosion potential of pretreated panels was measured, as a function of time, in $0.05 \mathrm{~mol} / \mathrm{L}$ $\mathrm{NaCl}$ solution employing a SCE as reference electrode. Measurements were done continuously for $2 \mathrm{~h}$ and after $25 \mathrm{~h}$.

\subsection{Duplex systems}

Taking into account the results obtained previously and the increases in energy consumption when the curing time is increased, the duplex systems were prepared on panels dried at $25^{\circ} \mathrm{C}$ and on panels cured for $1 \mathrm{~h}$. The panels were observed by scanning electron microscopy (SEM) and the layer formed on the surface, studied by energy dispersive X-ray analysis (EDXA).

Pretreated $10 \times 10 \mathrm{~cm}^{2}$ panels were dried at $25^{\circ} \mathrm{C}$ for $48 \mathrm{~h}$ (sample R), cured for $1 \mathrm{~h}$ at $100{ }^{\circ} \mathrm{C}$ (sample $\mathrm{C} 1$ ) or at $200^{\circ} \mathrm{C}$ (sample D1). Then, they were painted with an anticorrosive epoxy paint which was formulated with zinc molybdenum phosphate as anticorrosive pigment (Table 2). Paint elaboration was described elsewhere [12]. Panels were painted by brush up to a dry film thickness of $50 \pm 5 \mu \mathrm{m}$ and kept under laboratory conditions for 15 days for complete curing.

A short-handed notation was employed to name the duplex systems: panels DR were duplex system of panels R, panels DC1 were duplex system of panels C1, panels DD1 of panels D1, and panels DB were the control ones, galvanized steel painted without pretreatment.

A set of painted panels was placed in the salt spray chamber (ASTM B 117) and rusting (ASTM D 610) and blistering (ASTM D 714) degrees were evaluated after 1200, 2570, and $2900 \mathrm{~h}$. The adhesion of the coatings to the galvanized steel substrate was measured by the tape test (ASTM D 3359) before placing the panels in the salt spray chamber, after 504 and $984 \mathrm{~h}$ of exposition and when they were taken out of the chamber $(2900 \mathrm{~h})$. The FTIR analysis was done on delaminated areas in order to determine if the loss of adhesion occurred between the $\gamma$-GPS film and the substrate or between $\gamma$-GPS film and the organic coating. The wavelength range employed was from 650 to $4000 \mathrm{~cm}^{-1}$.

Electrochemical noise measurements (ENM) were done employing a three-electrodes cell with two nominally identical electrodes and a SCE as reference electrode. A low-value resistor was placed between the two specimens and current noise was measured as the fluctuation

Table 2. Composition of the paint.

\begin{tabular}{lc}
\hline Components & \% by volume of solids \\
\hline Zinc molybdenum phosphate & 9.8 \\
Barium sulfate & 11.9 \\
Talc & 6.6 \\
Titanium dioxide & 4.7 \\
Epoxy/polyamide resin & 67.0 \\
Anticorrosive pigment/total pigment (v/v) & 30 \\
\hline
\end{tabular}


in voltage across the resistor [13]. The three electrodes were in the same container which made it easier to control the effect of temperature fluctuations. The edges of the specimens were blanked off leaving $35.0 \mathrm{~cm}^{2}$ of the painted panel exposed to a $0.5 \mathrm{~mol} / \mathrm{L} \mathrm{NaCl}$. Data were acquired with a NICOLET 310 digital oscilloscope and the corresponding software 310RSWFT. The sensitivity of the measuring device in the E-scale was $100 \mu \mathrm{V}$ and $100 \mathrm{nA}$ in current measurements. The sampling frequency was $5 \mathrm{~Hz}$, which is commonly used to study corroding systems [14-16], and data were collected during $800 \mathrm{~s}$. Each set of data was controlled to verify they distribute normally [17]. Statistical analysis of each time series was performed and the noise resistance $\left(R_{\mathrm{n}}\right)$ was calculated as the quotient $R_{\mathrm{n}}=\sigma_{\mathrm{E}} / \sigma_{\mathrm{i}}$, being $\sigma_{\mathrm{E}}$ and $\sigma_{\mathrm{i}}$ the standard deviations of potential and coupling current, respectively [14-16].

The electrochemical noise test was ended after 145 days of immersion.

\section{Results}

\subsection{Pretreated galvanized steel}

The average amount of zinc, taking into account both sizes of the galvanized steel samples, was $240 \mathrm{~g} / \mathrm{m}^{2}$. The corresponding thickness, according to ASTM A 23/A123 M-09, was $17 \mu \mathrm{m}$, in good agreement with the average thickness measured employing the optic microscope $(14 \mu \mathrm{m})$. However, it was observed that the metallic coating thickness vary from 16.8 to $10.2 \mu \mathrm{m}$ (Figure 1).

Figures 2-4 showed the polarization curves of the $\gamma$-GPS/galvanized steel dried and cured at different temperatures and times comparing with the blank. In general, it can be seen that the cathodic reactions seemed to be more polarized than the anodic reactions and that there is not an important difference among the protected galvanized steel samples except in the case of the samples C0 and D0. These samples had slightly less protective performance than the others.

Figure 2 depicts the Tafel curves obtained after 1,6 , and $25 \mathrm{~h}$ of immersion of the samples dried at $25^{\circ} \mathrm{C}(\mathrm{R})$. After $1 \mathrm{~h}$ of immersion, the cathodic current of the blank was $\sim 3.6$ times higher than the corresponding one of the $\gamma$-GPS/galvanized steel; the anodic currents showed also higher values with respect to the pretreated sample, but after $6 \mathrm{~h}$, the differences disappeared. After $25 \mathrm{~h}$ of immersion, the measured cathodic currents of pretreated samples were higher at low overpotential, while the anodic currents were higher in the whole overpotential range. This behavior could be due to the presence of zinc oxides on the surface of the blank that partially blocks the reacting sites, diminishing the current.

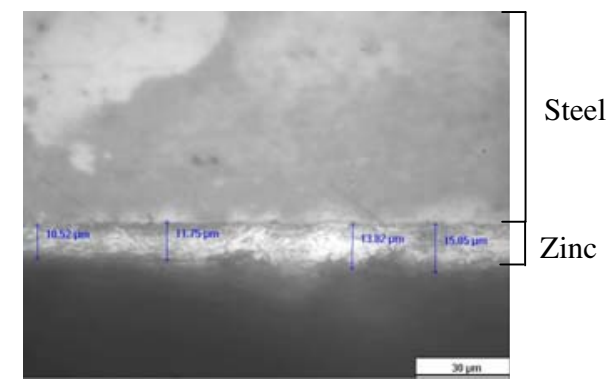

Figure 1. Transversal cut of the galvanized steel sheet, showing the thickness of the metal film in different zones. 


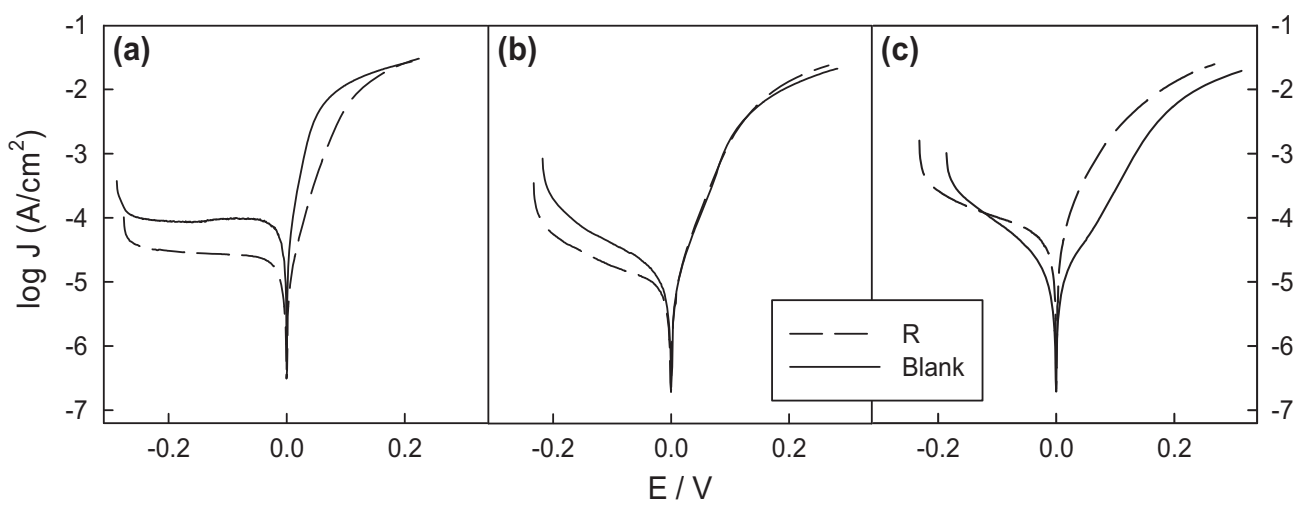

Figure 2. Tafel curves of $\gamma$-GPS/galvanized steel dried at $25^{\circ} \mathrm{C}(\mathrm{R})$ immersed in $0.5 \mathrm{~mol} / \mathrm{L} \mathrm{NaCl}$ for: (a) $1 \mathrm{~h}$, (b) $6 \mathrm{~h}$, and (c) $25 \mathrm{~h}$.

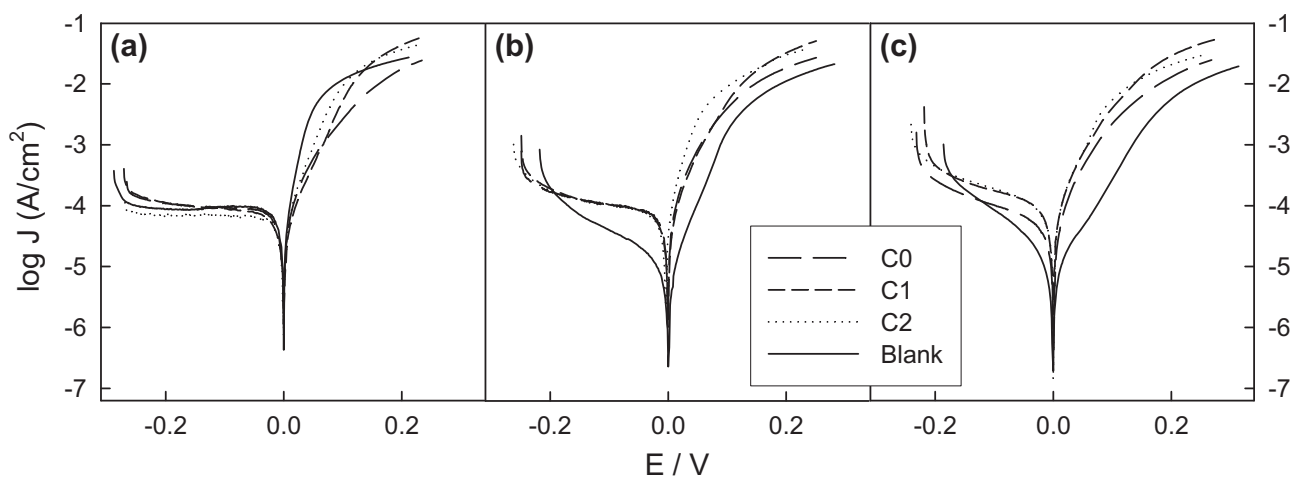

Figure 3. Tafel curves of $\gamma$-GPS/galvanized steel cured at $100^{\circ} \mathrm{C}$ for $0.5(\mathrm{C} 0), 1(\mathrm{C} 1)$, and $2 \mathrm{~h}(\mathrm{C} 2)$ immersed in $0.5 \mathrm{~mol} / \mathrm{L} \mathrm{NaCl}$ for: (a) $1 \mathrm{~h}$, (b) $6 \mathrm{~h}$, and (c) $25 \mathrm{~h}$.

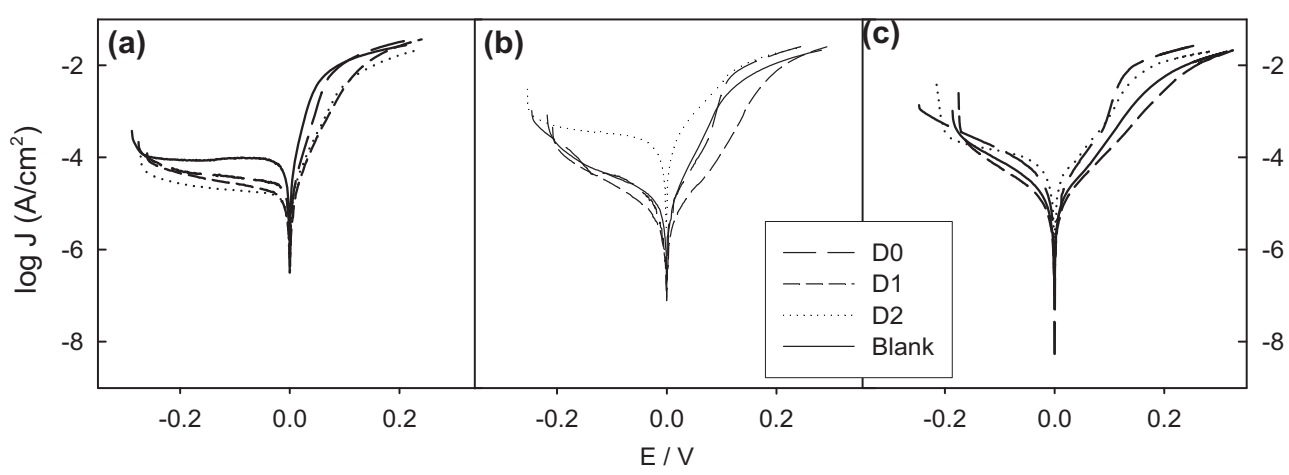

Figure 4. Tafel curves of $\gamma$-GPS/galvanized steel cured at $200^{\circ} \mathrm{C}$ for 0.5 (D0), 1 (D1), and $2 \mathrm{~h}$ (D2) immersed in $0.5 \mathrm{~mol} / \mathrm{L} \mathrm{NaCl}$ for: (a) $1 \mathrm{~h}$, (b) $6 \mathrm{~h}$, and (c) $25 \mathrm{~h}$. 
The cathodic current of the samples cured at $100^{\circ} \mathrm{C}$ (samples $\mathrm{C} 0, \mathrm{C} 1$ and $\mathrm{C} 2$ ) exhibited, after $1 \mathrm{~h}$ of immersion, values similar to those of the blank, $\mathrm{J} \sim 7-10.10^{-5} \mathrm{~A} \mathrm{~cm}^{-2}$ (Figure 3) while the anodic current of the blank was slightly higher. The similar values of the cathodic current imply that there is not a barrier protection due to the silane film. The cathodic current (at low overpotentials) as well as the anodic current of the blank was lower as time elapsed from 6 to $25 \mathrm{~h}$ due, as the samples cure at $25^{\circ} \mathrm{C}$, to the formation of oxides on the unprotected sample.

On the other hand, the cathodic current values of panels cured at $200{ }^{\circ} \mathrm{C}$ (samples D0, $\mathrm{D} 1$, and D2) were lower than those of the blank (B), after $1 \mathrm{~h}$ of immersion (around 2.7 times lower, Figure 4). After $6 \mathrm{~h}$, the cathodic currents were all similar except in the case of the sample D2 which was $\sim 7$ times higher. This behavior may be due to an increase of the active area in contact with the electrolyte. The anodic currents values depended on the curing time being lower for sample D1, higher for sample D2, and similar for sample D0. After $25 \mathrm{~h}$ of immersion, the anodic current values of the $200^{\circ} \mathrm{C}$-cured panels were not significantly different.

The polarization resistance with IR-drop compensation $\left(R_{\mathrm{p}}^{*}\right)$ was, in every case, higher than that of the blank, naked galvanized steel. These values diminished along time, but after $25 \mathrm{~h}$ of immersion, they were still 1.5-4.5 higher than in the case of the blank, being higher the values of the panels $\mathrm{C} 0, \mathrm{C} 1$, and $\mathrm{C} 2 . R_{\mathrm{p}}$ values had the same behavior as $R_{\mathrm{p}}^{*}$. There is only a slightly difference between $R_{\mathrm{p}}^{*}$ and $R_{\mathrm{p}}$ for each panels indicating that there is not an important barrier protection effect (Table 3 ) in agreement with the polarization curves data.

The corrosion currents were in every case lower than the one of the blank (71.6 and $104.5 \mu \mathrm{A} \mathrm{cm}^{-2}$ after 1 and $25 \mathrm{~h}$ of immersion, respectively), but they increase $1.5-2.5$ times as time elapsed because $\gamma$-GPS film, by itself, could not provide a long term protection (Table 3).

The differences in the corrosion potential values, Figure 5 and Table 3, among the samples were not significant except in the case of samples D1 and D2 that had values more positive than $-950 \mathrm{mV}$ for $50 \mathrm{~min}$, indicating that in these cases corrosion is more hindered that in the other samples. Since the first hour of immersion, the corrosion potential values of the other samples were closed to the corrosion potential of zinc that is under corrosion, $\sim-1010 \mathrm{mV}$, indicating that the substrate was equally active.

Table 3. Polarization resistance with $\left(R_{\mathrm{p}}^{*}\right)$ and without $\left(R_{\mathrm{p}}\right)$ iR drop compensation, corrosion current, and corrosion potential of the samples after 1 and $25 \mathrm{~h}$ of immersion in $\mathrm{NaCl} 0.05 \mathrm{~mol} / \mathrm{L}$.

\begin{tabular}{|c|c|c|c|c|c|c|c|c|}
\hline \multirow[b]{2}{*}{ Sample } & \multicolumn{2}{|c|}{$R_{\mathrm{p}}^{*}\left(\mathrm{k} \Omega \mathrm{cm}^{2}\right)$} & \multicolumn{2}{|c|}{$R_{\mathrm{p}}\left(\mathrm{k} \Omega \mathrm{cm}^{2}\right)$} & \multicolumn{2}{|c|}{$J\left(\mu \mathrm{A} / \mathrm{cm}^{2}\right)$} & \multicolumn{2}{|c|}{$-E_{\text {corr }}(\mathrm{mv})$} \\
\hline & $1 \mathrm{~h}$ & $25 \mathrm{~h}$ & $1 \mathrm{~h}$ & $25 \mathrm{~h}$ & $1 \mathrm{~h}$ & $25 \mathrm{~h}$ & $1 \mathrm{~h}$ & $25 \mathrm{~h}$ \\
\hline$R$ & 1.15 & 0.66 & 1.05 & 0.69 & 13.5 & 32.8 & 990 & 997 \\
\hline $\mathrm{C} 0$ & 2.46 & 1.02 & 2.25 & 1.22 & 12.7 & 30.5 & 979 & 1002 \\
\hline $\mathrm{C} 1$ & 2.65 & 1.19 & 2.82 & 1.25 & 9.6 & 20.5 & 996 & 1004 \\
\hline $\mathrm{C} 2$ & 2.92 & 1.54 & 2.67 & 1.61 & 10.6 & 20.2 & 985 & 1006 \\
\hline D0 & 1.19 & 0.54 & 1.19 & 0.69 & 26.1 & 57.2 & 993 & 1006 \\
\hline D1 & 1.74 & 0.63 & 1.12 & 0.80 & 20.5 & 46.7 & 941 & 997 \\
\hline D2 & 1.20 & 0.75 & 1.27 & 0.89 & 33.6 & 48.8 & 1008 & 989 \\
\hline B & 0.45 & 0.34 & 0.61 & 0.43 & 71.6 & 104.5 & 1010 & 1000 \\
\hline
\end{tabular}



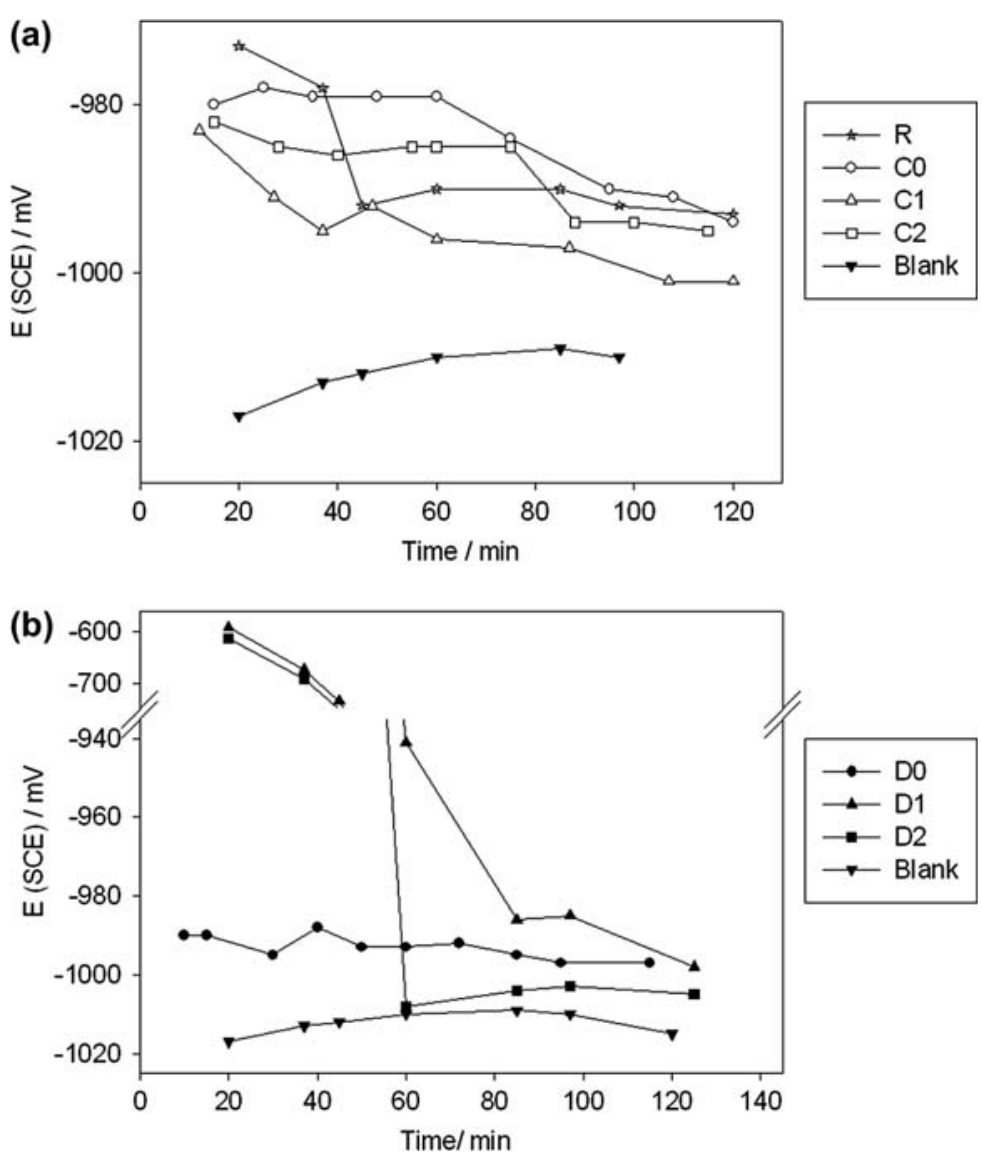

Figure 5. Corrosion potential of $\gamma$-GPS/galvanized steel cured at different times: (a) at $100{ }^{\circ} \mathrm{C}$ and (b) at $200^{\circ} \mathrm{C}$.

\subsection{Duplex systems}

In Figures 6-8 the SEM images of the pretreated panels can be seen.

The microphotograph of the sample cured at $25^{\circ} \mathrm{C}$ (Figure 6) showed, on the surface $(500 \times)$, particles rich of carbon and oxygen, probably dust, and a porous layer composed mainly by carbon, oxygen, and silicon; the high amount of zinc detected is due to the interference of the substrate $(8000 \times)$. The molar ratio between the atoms gave a $\mathrm{C} / \mathrm{O} / \mathrm{Si}$ ratio of $8.5 / 4.6 / 1$, the ratio of $\gamma$-GPS is $9 / 5 / 1$, indicating that the layer is silane with some degree of cross-linking as the amount of $\mathrm{C}$ and $\mathrm{O}$ are lower due to the hydrolysis of the methoxy groups of the silane and further condensation of the silanols. Some $\mathrm{MeOH}$ could be retained in the structure given higher amounts of $\mathrm{C}$.

When the curing temperature is rise, drops appeared on the panel surface $(500 \times)$, Figures 7 and 8 . The size of the drops increases with the increasing temperature and they are mainly compound of carbon, oxygen, and high amount of silicon in a ratio of $\mathrm{C} / \mathrm{O} / \mathrm{Si}$ of $3 / 2 / 1$, indicating the cross-linking of the silane. Moreover, taking into account the results of the molar ratio $\mathrm{C} / \mathrm{O} / \mathrm{Si}$ in the drops, part of the carbon chain in the $\gamma$-GPS structure was lost due to the curing temperature. Around the drops, a film can be seen, more homogenous, less porous, and more complex in the case of the sample cured at $100^{\circ} \mathrm{C}$ (Figure 7) than in the case of 
(a)

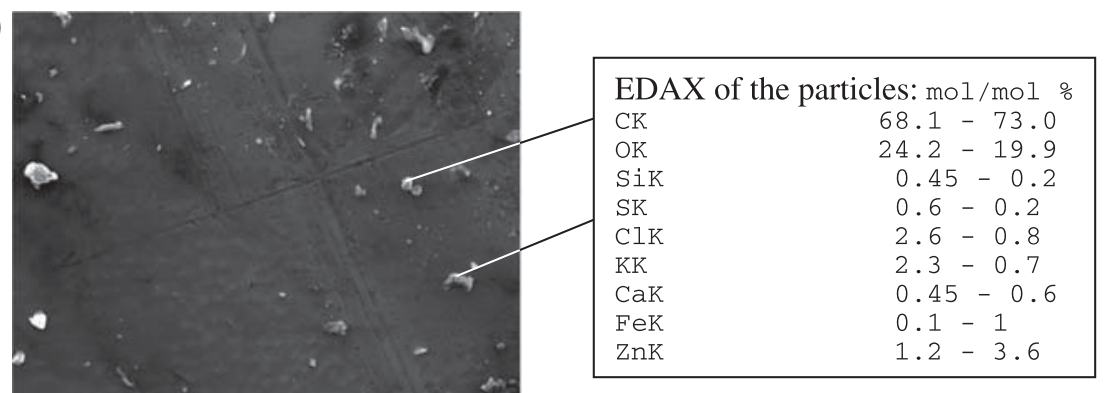

(b)

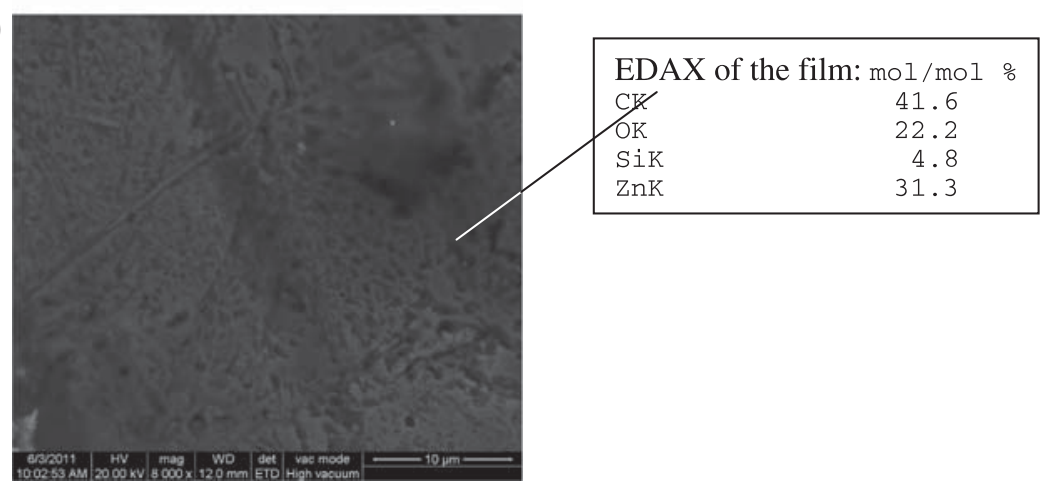

Figure 6. Microphotograph and EDX analysis (w/w\%, by weight) of panel with glymo cured at $25^{\circ} \mathrm{C}$ (R) (a) $500 \times$ and (b) $8000 \times$.

the panel cured at $200{ }^{\circ} \mathrm{C}$ (Figure 8). The films seemed to be formed of two layers, an upper one with a composition of $\mathrm{C} / \mathrm{O} / \mathrm{Si} 9.6 / 4.4 / 1$, indicating little or noncross-link or methanol retention and a lower one (underneath the first one) with a composition of $\mathrm{C} / \mathrm{O} / \mathrm{Si}=7.6 / 3.3 / 1$, indicating the presence of cross-linked silane.

Figure 9 showed the panel surface of the galvanized steel without pretreatment as a comparison for the surface morphology; the limits of the grain of the zinc deposit can be seen.

The results of the exposition to the salt spray chamber showed that the pretreated duplex systems protected steel better than the blank; no blisters appeared within $1200 \mathrm{~h}$. However, after $2900 \mathrm{~h}$, all tested panels blistered except the one identified as DD1 which had no blisters. In any case, corrosion signs appeared after this period.

The qualification of all unexposed panels in adhesion tests was 5B. The paint system applied on pretreated panels kept its adhesion to the substrate after $984 \mathrm{~h}$ of exposition in the salt spray chamber while the blank lost part of it (4B) after $504 \mathrm{~h}$. After $2900 \mathrm{~h}$, when the test was finished, painted panels DR, DC1, and DB had important adhesion failure: while DR and DB had delaminated areas, DC1 exhibited big blisters with low surface density (Table 4). This was not the case of painted panels DD1 which showed neither delamination nor blisters. Photographs of the painted panels removed from the chamber can be seen in Figure 10. The paint in the blistered area has been removed and the metal underneath did not showed corrosion signs, but the zinc coating was missed in certain areas due to the cathodic protection afforded by the metallic film. 
(a)

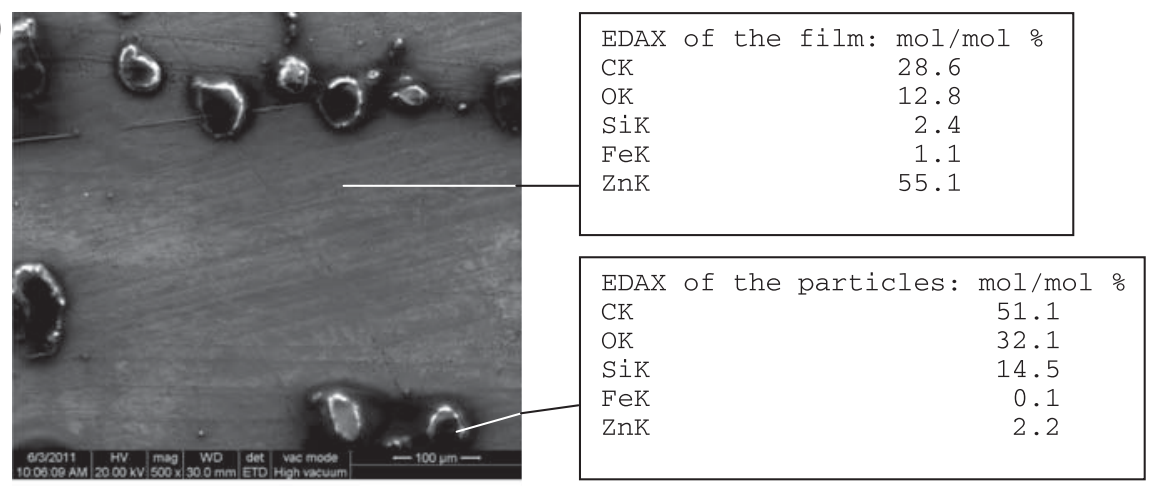

(b)

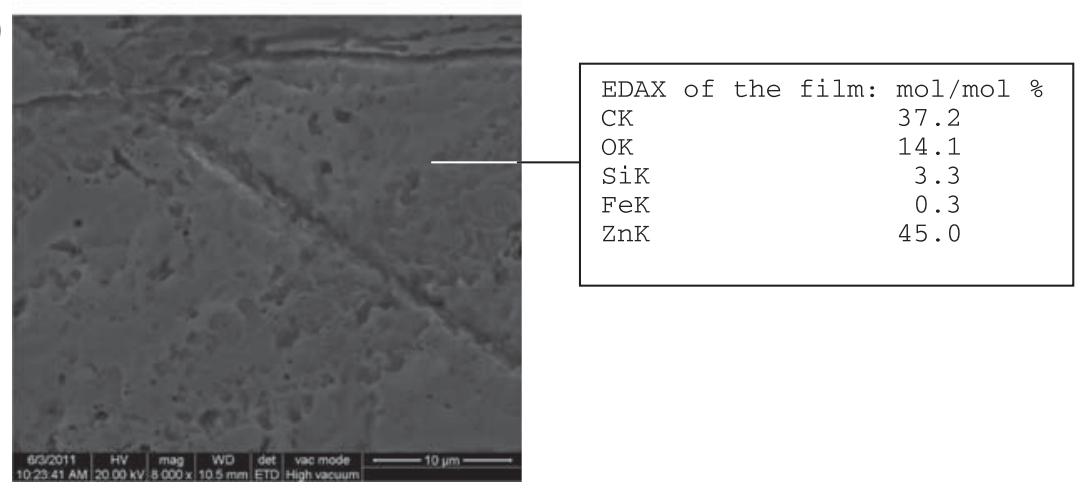

Figure 7. Microphotograph and EDX analysis (w/w\%, by weight) of the panels cured at $100^{\circ} \mathrm{C}$ for 1 h. (a) $500 \times$ (b) $8000 \times$.

The FTIR spectra of the delaminated area are shown in Figure 11. Some peaks can be seen around 1000 and $3500 \mathrm{~cm}^{-1}$, however, with very low intensity indicating that almost all the paint was lost from the metal surface. As these peaks appeared in the spectra of DR1, DC1, as well as in DB (blank without silane pretreatment) spectra, it was concluded that the adhesion failure took place between $\gamma$-GPS and the zinc coating and not between the $\gamma$-GPS pretreatment and the epoxy paint. On the other hand, the unpainted DD1 panels' spectra showed some paint left on the panel surface (peaks at 1082, 1508, 1632, 2854, and $2924 \mathrm{~cm}^{-1}$ ) indicating the adhesion was very good. In this case, the paint was removed bending the painted substrate.

Typical noise spectra of potential and coupling current of duplex systems DD1 and DB, after 105 days of immersion, can be seen in Figure 12(A) and 12(B), respectively. The Gaussian distributions of these spectra are also shown.

Noise corrosion potential (Figure 13) of panels DR and DB presented peaks within the first days of immersion with values near $-650 \mathrm{mV}$; this fact may be due to active-passive transitions of the metal. In the case of DD1, passivation was also observed after the first week of immersion, but then, the potential values dropped reaching those of the blank after 70 days. The corrosion potential of the duplex system DC1 rapidly reached potential values near to $-1000 \mathrm{mV}$.

As a general rule, the coupling current values were around $10^{-2} \mathrm{~mA} \mathrm{~cm}^{-2}$ during the whole essay (Figure 14). Galvanized steel without pretreatment, panels DB, presented current 


\section{(a)}

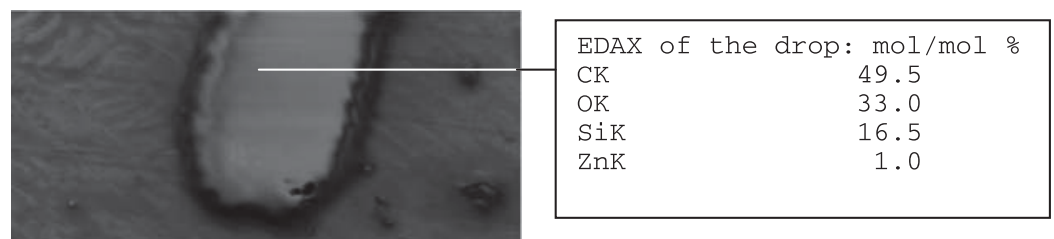

(b)

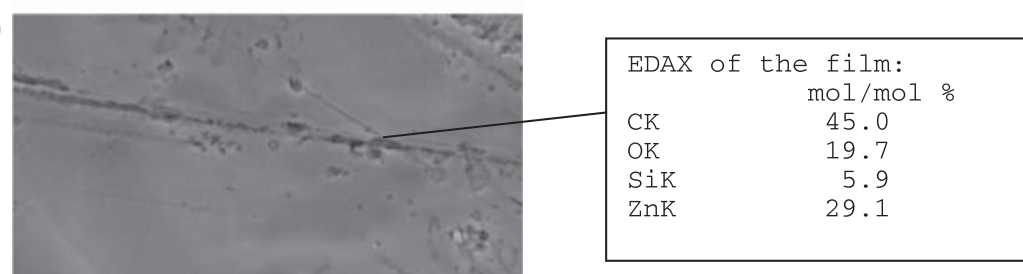

Figure 8. Microphotograph and EDX analysis (w/w\%, by weight) of the panels cured at $200^{\circ} \mathrm{C}$ for 1 h. (a) $500 \times$ and (b) $8000 \times$.

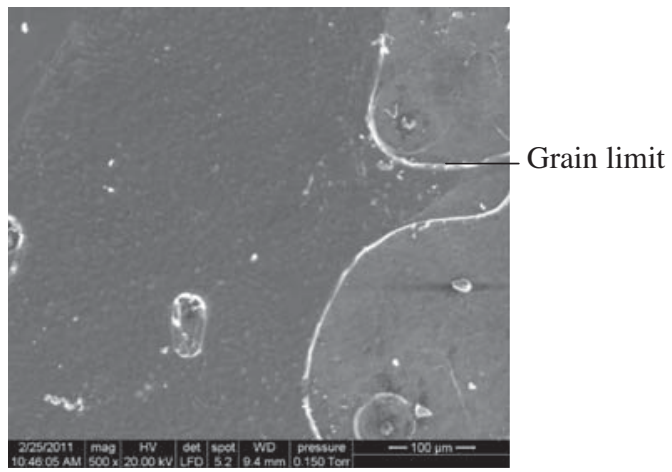

Figure 9. Microphotograph of the control panel $500 \times$.

peaks during the first week and after 100 days of essay while for panels DC1, a peak appeared after 132 days of immersion. In both cases, the peaks may be attributed to the unblocking of pores due to corrosion products removal.

The noise resistance values can be seen in Figure 15. These values are relatively low, they do not surpass $5500 \Omega \mathrm{cm}^{2}$, and they follow the same general behavior, with peaks that would indicate restrictions to the corrosion reaction due to the accumulation of corrosion products. 
Table 4. Results of the salt spray test.

\begin{tabular}{|c|c|c|c|c|c|c|}
\hline \multirow[b]{2}{*}{ Duplex system } & \multicolumn{2}{|c|}{$1200 \mathrm{~h}$} & \multicolumn{2}{|c|}{$2570 \mathrm{~h}$} & \multicolumn{2}{|c|}{$2900 \mathrm{~h}$} \\
\hline & $\mathrm{C}^{*}$ & $\mathrm{~B}^{*}$ & $\mathrm{C}^{*}$ & $\mathrm{~B}^{*}$ & $\mathrm{C}^{*}$ & $\mathrm{~B}^{*}$ \\
\hline DR & 10 & 10 & 10 & 10 & 10 & $\mathrm{DA}^{*}$ \\
\hline $\mathrm{DC} 1$ & 10 & 10 & 10 & $2 \mathrm{~F}$ & 10 & $2 \mathrm{~F}$ \\
\hline DD1 & 10 & 10 & 10 & 10 & 10 & 10 \\
\hline DB & 10 & $2 \mathrm{~F}$ & 10 & $2 \mathrm{~F}$ & 10 & $\mathrm{DA}^{*}$ \\
\hline
\end{tabular}

$\mathrm{C}^{*}$ : Corrosion degree; $\mathrm{B}^{*}$ : Blistering degree; $\mathrm{DA}^{*}$ : delaminated areas.

(a)

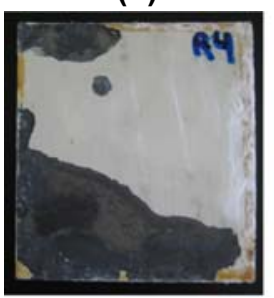

(b)

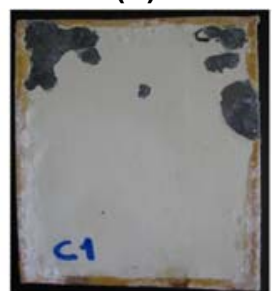

(c)

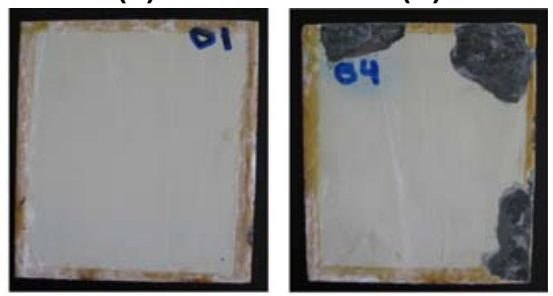

\begin{tabular}{|c|c|c|c|c|c|c|c|c|c|c|}
\hline Rusting degree & 10 & 9 & 8 & 7 & 6 & 5 & 4 & 3 & 2 & 1 \\
\hline rusted area / \% & 0 & 0.03 & 0.1 & 0.3 & 1 & 3 & 10 & 16 & 33 & 50 \\
\hline
\end{tabular}

\begin{tabular}{|c|c|c|c|c|}
\hline \multicolumn{5}{|c|}{ Blistering degree } \\
\hline Frequency & Dense, D & Medium dense, MD & Medium, M & Few, F \\
\hline \hline Size & 10 & 8 & $6,4,2$ \\
\hline Comments & No blistering & Smaller size blister easily seen by unaided eye & Progressively larger sizes \\
\hline
\end{tabular}

Figure 10. Photographs of the panels removed from salt spray chamber showing adhesion failure: (a) DR duplex system, (b) DC1 duplex system, (c) DD1 duplex system, and (d) DB duplex system.

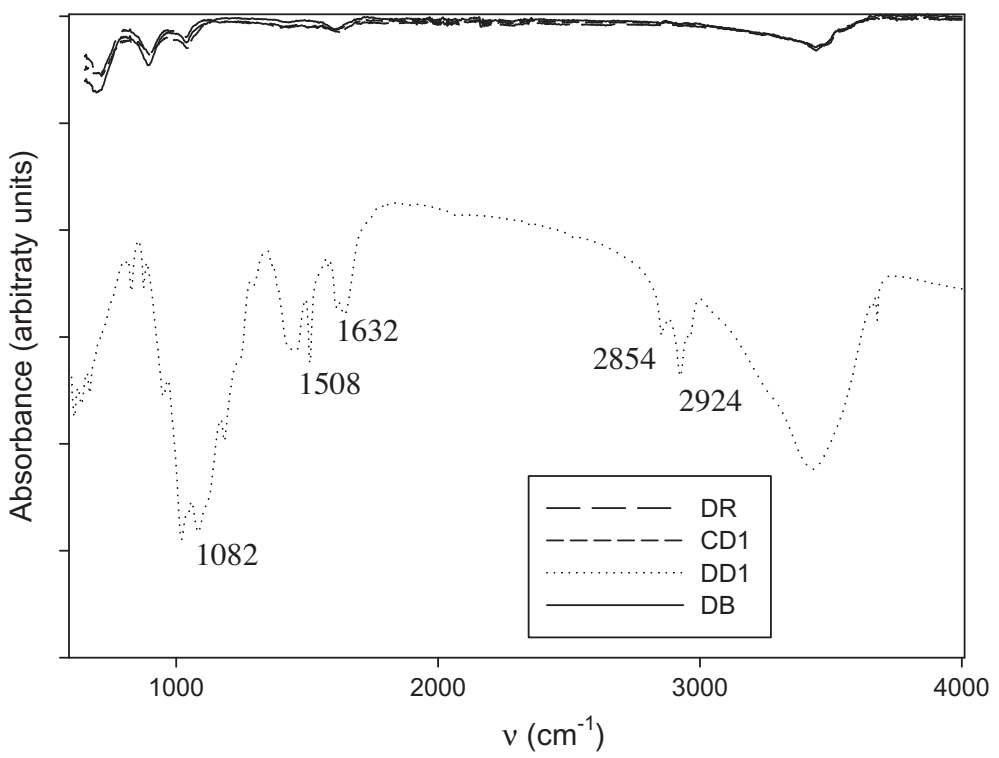

Figure 11. Spectra of the unpainted panels after salt spray exposition. 

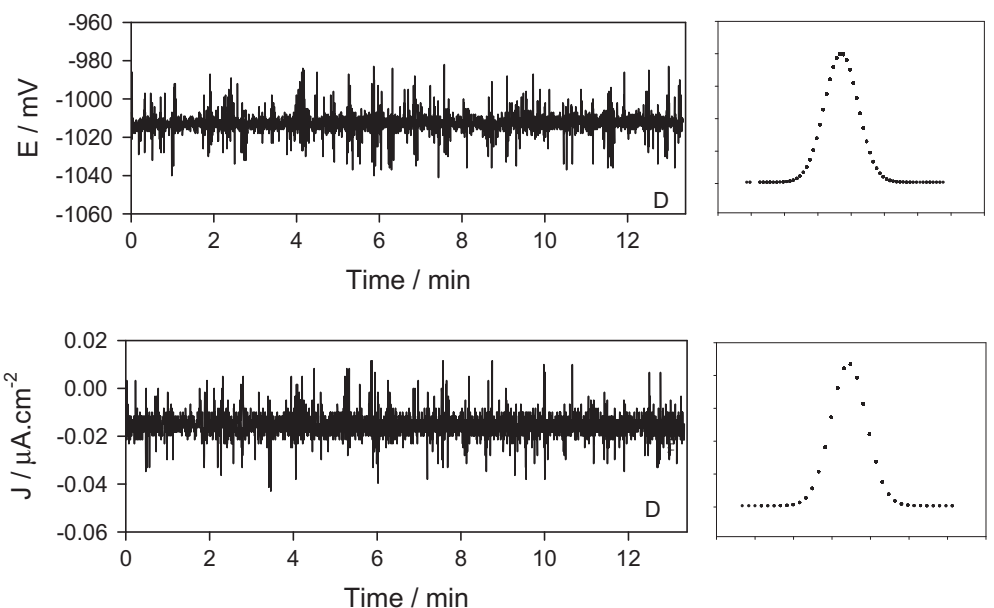

Figure 12A. Noise spectra and Gauss graph for DD1 after 105 days of immersion.
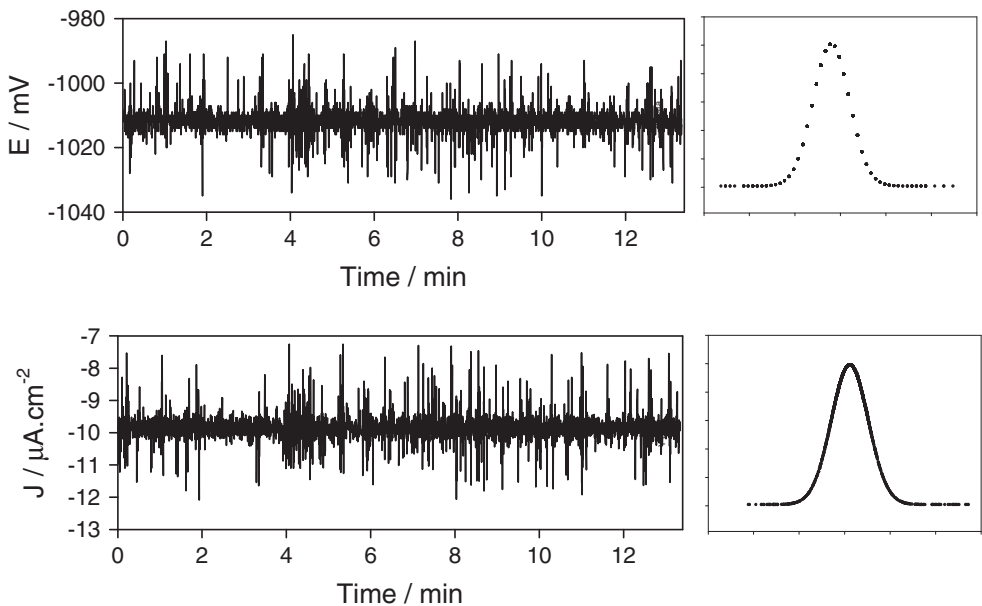

Figure 12B. Noise spectra and Gauss graph for DB after 105 days of immersion.

\section{Discussion}

Some problems appeared when results obtained employing $\gamma$-GPS as adhesion promoter were compared with other promoters or other pretreatments for duplex system; mainly, the lack of an agreement among the researchers about which accelerated tests must be done to evaluate these compounds.

Sathyanarayana and Yaseen [4] compared a polyaniline primer with a chromate-base primer $10 \mu \mathrm{m}$ thick, employing electrochemical techniques. In both cases, the corrosion potential $\left(E_{\text {corr }}\right)$ fluctuated around $-1040 \mathrm{mV}$ from the beginning of the test and up to approximately $400 \mathrm{~h}$. The corrosion potential of the $\gamma$-GPS pretreated galvanized steel was measured during, only, $25 \mathrm{~h}$; however, the values were also around $-1010 \mathrm{mV}$, so it may be said that the results are comparable as they were immersed in the same electrolyte.

Many authors employed the salt spray chamber test (ASTM B 117) to evaluate the anticorrosive performances of duplex systems. Palraj et al. [18] studied three different pretreatment with a $50 \mu \mathrm{m}$ epoxypolyamide/red oxide paint. They claimed that no white cor- 


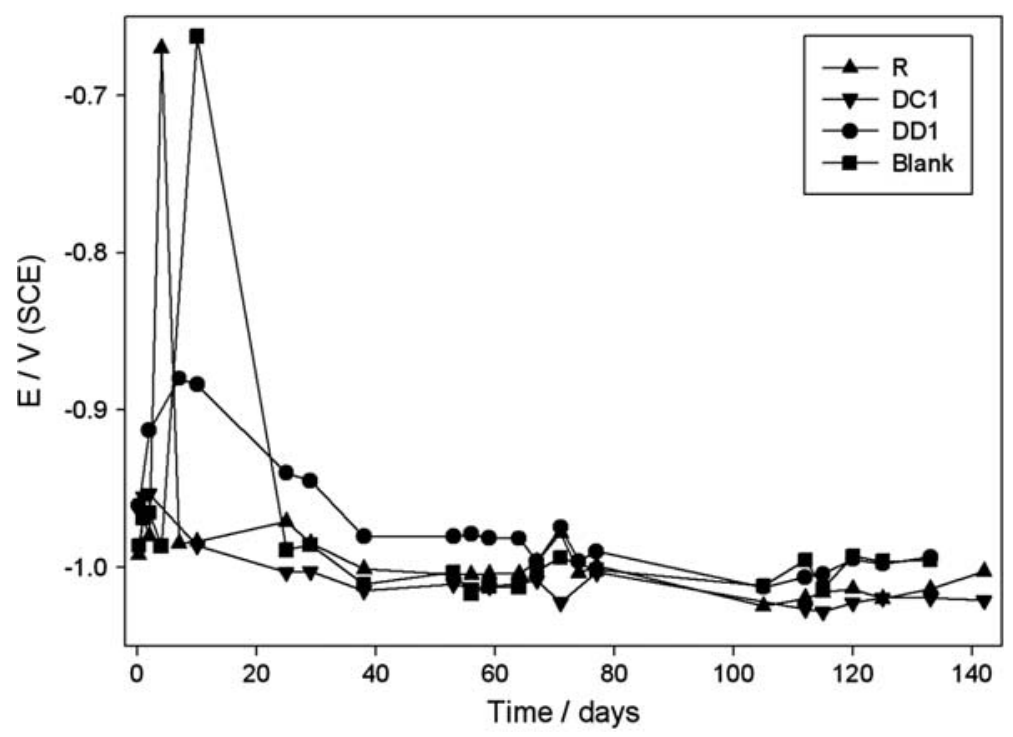

Figure 13. Noise corrosion potential of the duplex systems.

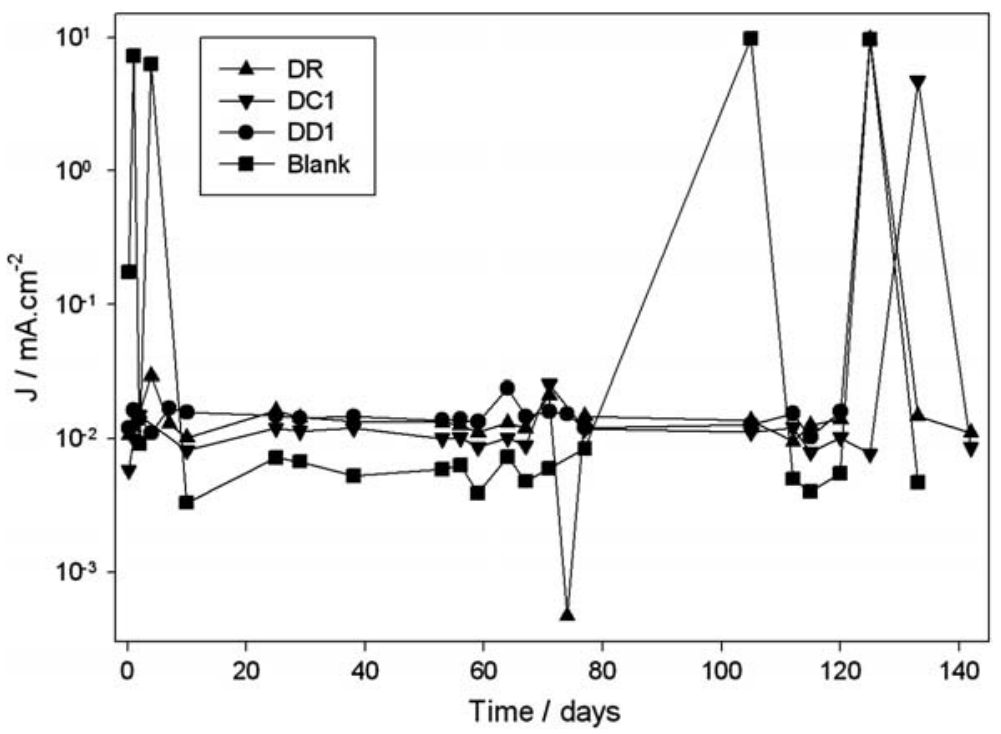

Figure 14. Noise corrosion current of the duplex systems.

rosion appeared on the exposed panels after 720 h. Edavan and Kopinsky [19] studied chrome-phosphate and chrome-free pretreatments with polyester as film forming material, $23 \mu \mathrm{m}$ of total dried thickness. The protection afforded by this duplex system lasted $2000 \mathrm{~h}$; however, blistering appeared on the panels. A pretreatment with $\mathrm{Fe}\left(\mathrm{NO}_{3}\right)_{3}$ and $\mathrm{H}_{3} \mathrm{PO}_{4}$ and different anticorrosive primers plus a top coat was studied by del Amo et al. [1]. The total thickness of these coating systems was $125 \mu \mathrm{m}$. These painted panels received a qualification higher than seven after $2328 \mathrm{~h}$ (97 days) in the salt spray test. As it could be expected, results depended on the type of resin employed in the primer formulation being epoxypolyamine solvent-borne paint qualified with eight. 


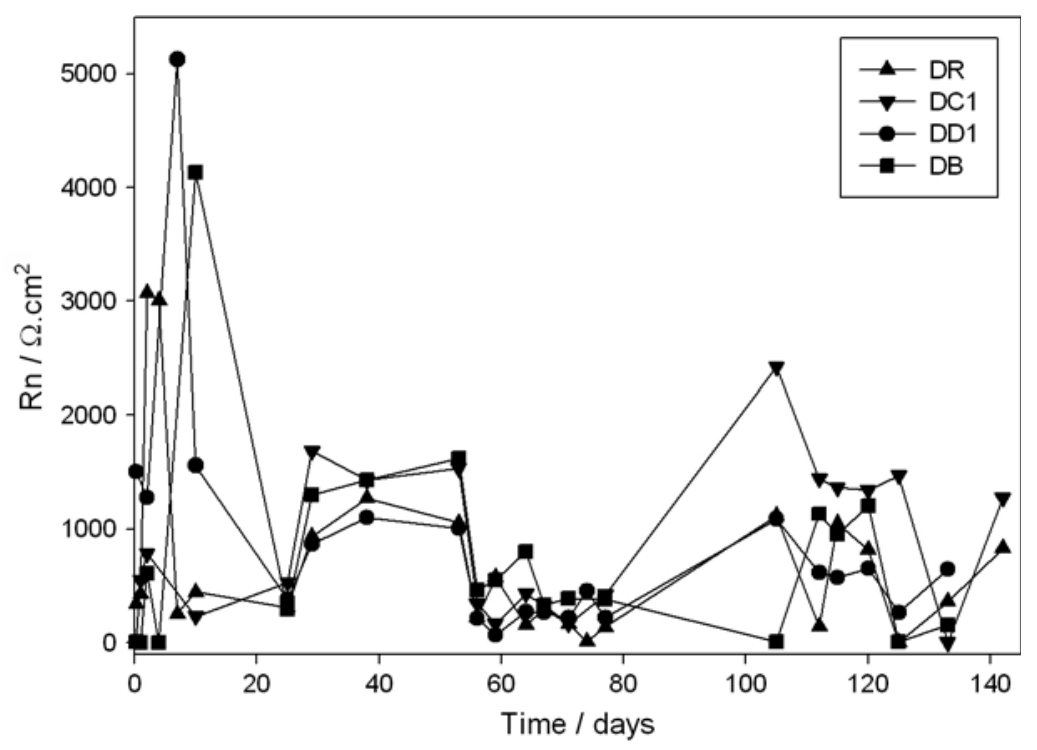

Figure 15. Noise resistance of the duplex systems.

The duplex systems with $\gamma$-GPS as pretreatment, with a total dried thickness of $50 \mu \mathrm{m}$, lasted $1200 \mathrm{~h}$ without corrosion spots or blisters and after $2570 \mathrm{~h}$, only panels cured at $100^{\circ} \mathrm{C}$ and the blank had blisters $(2 \mathrm{~F})$; again, the results are comparable taking into account the differences in organic coating systems.

The adhesion tests done by del Amo et al. [1] and Edavan and Kopinski [19], employing the tape-test method (ASTM D 3359), resulted in 4B-5B qualification for all the painted panels, under dried conditions. After $2328 \mathrm{~h}$ (97 days) in the salt spray chamber, del Amo et al. determined the wet adhesion resulting in $0 \mathrm{~B}$ for acrylic and water-borne epoxy system, $2 \mathrm{~B}$ for alkyd, and 5B for the other two systems studied. Edavan and Kopinski [19] did not evaluate the wet adhesion. Palraj et al. [18] evaluate only dried adhesion but employing the pull off test.

In the case of the $\gamma$-GPS duplex system, the dried adhesion was 5B for all the curing conditions and it remained constant for $984 \mathrm{~h}$ (41 days) in the salt spray cabinet.

Taking into account the previous discussion, it must be noticed that there is not an understanding about which tests or coating characteristics are the most suitable to compare adequately the adhesion and the anticorrosive performance of different duplex systems. However, the results analyzed previously and those obtained in this research showed that $\gamma$-GPS pretreatment + epoxy solvent-borne paints protected steel similarly to other methods with the advantage of not having any environmental concern. The better performance of the samples cured at $200^{\circ} \mathrm{C}$ may be due to the formation of drops of cross-linked $\gamma$-GPS $(>100 \mu \mathrm{m})$ on the surface that enhance the adhesion of the paint to the galvanized substrate. Despite the silane film formed in this case seemed to be more homogenous and less porous than the ones obtained at $100^{\circ} \mathrm{C}$ and at $25^{\circ} \mathrm{C}$, it is not enough to protect the steel by a barrier effect $\left(R_{p}^{*} \sim R_{\mathrm{p}}\right)$.

\section{Conclusions}

(1) The films of $\gamma$-GPS formed on galvanized steel diminished the corrosion current of the metal, but they do not protect the substrate by a barrier effect. 
(2) The incorporation of the pretreatment with $\gamma$-GPS in the duplex system increased the adhesion of the paint, especially when the pretreated substrate was cured $1 \mathrm{~h}$ at $200^{\circ} \mathrm{C}$. A certain tendency to blister was detected at lower curing temperatures.

(3) The $\gamma$-GPS pretreatment do not change the electrochemical properties of the duplex system.

(4) It is important to discuss which are the most reliable and rapid test to evaluate duplex system as the amount of tests and essays in the field make the comparison between the systems very difficult.

\section{Acknowledgements}

The author thanks to CONICET (Consejo Nacional de Investigaciones Científicas y Técnicas), UNLP (Universidad Nacional de La Plata), and CIC (Comisión de Investigaciones Científicas de la Provincia de Buenos Aires) for the support to do this research and to Bernardo Browne and Andrés Campbell from CamSi-X for providing the silane to do this work.

\section{References}

[1] del Amo B, Veleva L, Di Sarli A, Elsner C. Performance of coated steel systems exposed to different media, Part I: painted galvanized steel. Prog. Org. Coat. 2004;20:179-192.

[2] Carter VE. in Corrosion, L. L. Shreir editor, Newnwe-Butterworths, London, 1976.

[3] Cabanelas I, Collazo A, Izquierdo M, Nóvoa X, Pérez C. Influence of galvanized surface state on the duplex systems behaviour. Corr. Sci. 2007;49:1816-1832.

[4] Sathyanarayana M, Yaseen M. Role of promoters in improving adhesion of organic coatings to a substrate. Progr. Org. Coat. 1995;26:275-313.

[5] Bexell U, Grehk T. A corrosion study of hot-dip galvanized steel sheet pretreated with g-mercaptopropyltrimethoxysilane. Surf. Coat. Technol. 2007;201:4734-4742.

[6] Petrie E. Adhesion \& bonding. Metalfinish, July/August. 2007:85-93.

[7] Osborne JH, Blohowiak KY, Ray Taylor S, Hunter C, Bierwagen G, Carlson B, Bernard D, Donley $\mathrm{M}$. Testing and evaluation of nonchromated coating systems for aerospace applications. Prog. Org. Coat. 2001;41:217-225.

[8] Fedel M, Olivier M, Poelman M, Deflorian F, Rossi S, Druart M-E. Corrosion protection properties of silane pre-treated powder coated galvanized steel. Prog. Org. Coat. 2009;66:118-128.

[9] Zheludkevich M, Miranda Salvado I, Ferreira M. Sol-gel for corrosion protection of metals. J. Mater. Chem. 2005;15:5099-5111.

[10] Abel M, Watts J, Digby R. The influence of process parameters on the interfacial chemistry of g-GPS on aluminum: a review. J. Adhes. 2004;80:291-312.

[11] Bertelesen C, Boerio F. Linking mechanical properties of silanes to their chemical structure: an analytical study of g-GPS solutions and films. Prog. Org. Coat. 2001;41:239-246.

[12] Vetere V, Deyá C, Romagnoli R, del Amo B. Calcium tripolyphosphate: an anticorrosive pigment for paint. J. Coat. Technol 2001;73:57-63.

[13] Roberge PR, Beaudoin R, Sastri VS. Electrochemical noise measurements for field applications. Corr. Sci. 1989;29:1231-1233.

[14] Kearns JR, Scully JR, Roberge PR, Reichert DL, Dawson JL editors, Electrochemical noise measurements for corrosion applications. West Conshohocken: ASTM, STP 1277; 1996.

[15] Cottis RA. Interpretation of electrochemical noise data. Corrosion. 2001;57(3):265-284.

[16] Huet F. Electrochemical noise technique. In: Marcus P, Mansfeld F, editors. Analytical methods in corrosion science and engineering. Boca Raton: CRC Taylor \& Francis; 2005. p. 507-568.

[17] Mabbutt S, Mills DJ, Woodcock CP. Development of electrochemical noise method (ENM) for more practical assessment of anticorrosive coating. Prog. Org. Coat. 2007;59:192-196.

[18] Palraj S, Selvaraj M, Jayakrishnan P. Effect of phosphate coatings on the performance of epoxy polyamide red oxide primer on galvanized steel. Prog. Org. Coat. 2005;51:5-9.

[19] Edavan R, Kopinski R. Corrosion resistance of painted zinc alloy coated steels. Corr. Sci. 2009;51:2429-2442. 